\title{
Winery distillery waste compost effect on the performance of melon crop under field conditions
}

\author{
Raquel Villena ${ }^{1}$, María Teresa Castellanos ${ }^{1 *}$, María Carmen Cartagena ${ }^{1}$, Francisco Ribas ${ }^{2}$, Augusto Arce $^{1}$, María Jesús Cabello ${ }^{2}$, María \\ Isabel Requejo²
}

\begin{abstract}
${ }^{1}$ Technical University of Madrid/School of Agricultural, Food and Biosystems Engineering - Dept. of Chemistry and Food Technology, Av. Puerta del Hierro, 2 - 28040 - Madrid Spain.

${ }^{2}$ Agri-Food and Forestry Regional Research and Development Centre/El Chaparrillo Agro-environmental Research Centre, Ctra. Ciudad Real-Las Casas, km 3.5 - Ciudad Real - Spain. *Corresponding author <mariateresa.castellanos@upm.es>
\end{abstract}

Edited by: Mohammad Valipour

Received December 28, 2016

Accepted September 15, 2017
ABSTRACT: The substantial generation of organic waste together with increasing interest in developing sustainable agriculture heralds an opportunity for mobilizing the recycling of these materials as a source of organic matter and nutrients into a viable management strategy option. A field experiment was conducted to evaluate the use of compost derived from waste produced by the winery and distillery industries in a drip-irrigated melon crop traditionally grown in the area where these wastes are generated. A randomized complete block design was used with four treatments consisting of three different dose levels of compost: 7 (D1), 13 (D2) and 20 (D3) t $\mathrm{ha}^{-1}$ and a control (DO) without the application of compost. The effects of these treatments on plant growth, nitrogen $(\mathrm{N})$ and phosphorus $(\mathrm{P})$ accumulation as well as fruit yield and quality were studied. The application of compost produced a slight increase in plant biomass accompanied by changes in the relative growth rate (RGR) and net assimilation rate (NAR). As a result, a significant improvement in fruit yield was observed in the plots amended with $D 2$, which met all the requirements to obtain elevated yields. In terms of environmental correctness applications were below the limits established by a number of impact indexes. Additionally, the application of compost improved fruit quality resulting in an enhancement of Brix degrees. Although the potential effects of $\mathrm{N}$ and $\mathrm{P}$ derived from compost were partially masked by other inputs of these nutrients into the system ( $\mathrm{N}$ in irrigation water, $\mathrm{P}$ supplied through fertigation), an effect of $\mathrm{P}$ was observed resulting in an increase in the number of individual fruits in the plots amended with compost.

Keywords: Cucumis melo, growth, yield, nitrogen, phosphorus

\section{Introduction}

Developing new sustainable production practices to improve crop yield and quality is attracting great interest. Spain is the world's fourth-largest producer of wine $(\mathrm{FAO}, 2013)$ and its winery and distillery industries generate substantial amounts of residues for a short period each year (from Aug to Oct) which have polluting characteristics such as low $\mathrm{pH}$ and phytotoxic and antibacterial phenolic substances (Bustamante et al., 2008a). During the winemaking process, solid residues such as grape stalks are generated, as well as grape marc (comprising the skin, pulp and seeds of the grape) and wine lees as by-products. Grape marc and wine lees are usually sent to alcohol distilleries where exhausted grape marc, cake lees and vinasses are generated. The composting of these waste products has been shown to be a feasible option for use in agricultural soils, as sources of nutrients and organic matter which does not cause environmental damage (Bustamante et al., 2008b; Requejo et al., 2014).

The winery industry is located mainly in Mediterranean agroecosystems, characterised by semiarid conditions. Horticultural crops have also been traditionally grown in these areas with high inputs of water and fertilizers. Thus, the utilization of compost derived from winery and distillery residues may offer sustainable potential for improving the yield and quality of crops in the area where they are generated. Spain is the main
European producer of melon (MAPAMA, 2013). For the main part, melon is cultivated in zones vulnerable to nitrate pollution in the center of Spain (Directive 91/676/ $\mathrm{EECl}$, where more than half of the total wine production of the country is concentrated (MAPAMA, 2013). Thus, the application of any amendment is of special interest to this area from both an economic and an environmental point of view, given the goal of securing maximum yield with minimum water and fertilizer consumption and minimum loss of N (Castellanos et al., 2012; Requejo et al., 2014).

Previous studies have demonstrated positive effects after the application of winery and distillery waste composts to horticultural crops in both transplant production (Carmona et al., 2012) and vegetable production under greenhouse conditions (Inácio et al., 2000); however, there is a lack of information regarding its use under open-field conditions. The aim of this work was to evaluate the effect of the use of compost derived from winery and distillery waste on growth, the uptake of nitrogen $(\mathrm{N})$ and phosphorus $(\mathrm{P})$, and the quality and yield of a drip-irrigated melon crop under field conditions.

\section{Materials and Methods}

\section{Experimental design}

Field trials were conducted in adjacent and separated plots at La Entresierra field station in Ciudad Real, central Spain $\left(3^{\circ} 56^{\prime} \mathrm{W} ; 39^{\circ} 0^{\prime} \mathrm{N} ; 640 \mathrm{~m}\right.$ altitude) during 
the growing seasons of 2011 and 2012. Soil characteristics are detailed in Table 1 . The soil at the experimental site is a shallow sandy-loam, classified as Petrocalcic Palexeralfs (Soil Survey Staff, 2014) with a depth of 0.6 $\mathrm{m}$ and a discontinuous petrocalcic horizon between 0.6 and $0.7 \mathrm{~m}$. For the previous three years, the plots had been cultivated with non-irrigated wheat (Triticum aestivum L.) and were subjected to no organic amendment nor fertilizers. The area is characterised by a continental Mediterranean climate, with widely fluctuating daily temperatures and an average annual rainfall of $400 \mathrm{~mm}$, mostly distributed outside the melon growing period. The minimum, maximum and average air temperature during the experimental period of 2011 were 13.0, 30.5 and $21.7^{\circ} \mathrm{C}$ respectively; and in 2012 were 11.0, 29.8 and $20.4{ }^{\circ} \mathrm{C}$ respectively (Requejo et al., 2014).

The compost used in this experiment was sourced from a composting plant located in Socuéllamos (Ciudad Real) which collects residues from the wineries and distilleries throughout this area and via an aerobic process produces a commercial compost composed of grape stalks, dealcoholized grape marc and cake lees. The compost applied to the plots in the experiment was made from the winery waste from the previous harvest. The main properties of the compost used are described more fully in Requejo et al. (2014) (Table 1) and this compost fulfills the criteria established by the Spanish legislation governing the use of organic materials in agriculture.

The experimental design was a randomized complete block with the dose of compost as a variable factor. Four treatments with four replications were each administered in both years comprising a control with no compost addition (D0), and three doses of wine-distillery waste compost application corresponding to 7 (D1), 13 (D2) and 20 (D3) $\mathrm{t} \mathrm{ha}^{-1}$.

The compost was applied on 20 Apr 2011 and 19 Apr 2012 using a tow-behind spreader, was mixed with the soil at approximately a depth of $10 \mathrm{~cm}$ localized in the crop row, and immediately covered over with soil.

For each year of experimentation, melon seeds of the 'Piel de Sapo' melon (Cucumis melo L. cv. Trujillo)

Table 1 - Characterization of the soil and compost used in the experiments.

\begin{tabular}{lrcc}
\hline & \multirow{2}{*}{ Soil } & \multicolumn{2}{c}{ Compost } \\
\cline { 3 - 4 } & & 2011 & 2012 \\
\hline Sand (\%) & 70.4 & - & - \\
Silt (\%) & 8.0 & - & - \\
Clay (\%) & 21.6 & - & - \\
$\mathrm{pH}$ & 8.4 & 9.2 & 9.8 \\
$\mathrm{EC}\left(\mathrm{mS} \mathrm{cm}^{-1}\right)$ & 0.2 & 1.2 & 1.0 \\
Organic carbon $\left(\mathrm{g} \mathrm{kg}^{-1}\right)$ & 14.0 & 316.9 & 348.8 \\
$\mathrm{~N}^{*}\left(\mathrm{~g} \mathrm{~kg}^{-1}\right)$ & 1.0 & 32.9 & 33.0 \\
$\mathrm{NO3}^{-N}\left(\mathrm{mg} \mathrm{kg}^{-1}\right)$ & 15.3 & 244 & 295 \\
$\mathrm{NH} 4-\mathrm{N}\left(\mathrm{mg} \mathrm{kg}^{-1}\right)$ & 1.7 & 1.5 & 1.8 \\
$\mathrm{C} / \mathrm{N} \mathrm{ratio}$ & 14.0 & 10.1 & 11.2 \\
\hline${ }^{*}$ Determined by the Kjeldahl method. Source: Requejo et al., 2016a.
\end{tabular}

were germinated under greenhouse conditions from late March until they had brought forth two or three real leaves. The seedlings were transplanted into the soil covered with transparent plastic mulch on 11 May 2011 and 9 May 2012 at a density of 4,444 plants ha ${ }^{-1}(1.5 \times$ $1.5 \mathrm{~m})$, approximately 20 days after the application of compost.

The plots $\left(12 \times 15 \mathrm{~m}^{2}\right)$ had ten rows of eight plants each. Each row was irrigated by a drip line and emitters of $2 \mathrm{~L} \mathrm{~h}^{-1}, 0.5 \mathrm{~m}$ apart. The irrigation requirements were calculated daily using the FAO method $(\mathrm{ETc}=\mathrm{Kc}$ $\times \mathrm{ET}_{0}$, Doorenbos and Pruitt, 1977). $\mathrm{ET}_{0}$ was the evapotranspiration reference and was estimated by the FAO Penman-Monteith method (Allen et al., 2002), using daily data from a meteorological station located near the experimental field. Kc is the crop coefficient obtained in previous years for melon crop under the same conditions (Cabello et al., 2009). The irrigation quality was measured weekly and the main properties appear in Requejo et al. (2014). Total irrigation applied was $341 \mathrm{~mm}$ in the first year, and $461 \mathrm{~mm}$ in the second. The nitrate concentration in the irrigation water was $116.0 \pm 8.2$ and $125.0 \pm 8.1 \mathrm{mg} \mathrm{L}^{-1}$ in 2011 and 2012 respectively, the potassium concentration $3.6 \pm 0.5$ and $3.5 \pm 0.5 \mathrm{mg}$ $\mathrm{L}^{-1}$ in 2011 and 2012 respectively, and the phosphorus concentration $16 \pm 2 \mu \mathrm{g} \mathrm{L} \mathrm{L}^{-1}$.

All treatments received $120 \mathrm{~kg} \mathrm{ha}^{-1}$ of $\mathrm{P}_{2} \mathrm{O}_{5}$ (phosphoric acid) for the whole season, injected daily through the drip-irrigation system, starting with the irrigation scheduling. In 2011 they were applied beginning 27 days after transplanting (DAT), after the female flowering phase. However, in 2012, the phosphorus application was initiated 21 DAT, before the female flowering phase. Nitrogen fertilizers were not applied due to the high concentration of dissolved nitrates in the irrigation water (116 and $125 \mathrm{mg} \mathrm{NO}_{3} \mathrm{~L}^{-1}$ in 2011 and 2012, respectively (Requejo et al., 2014)). Due to the high content of potassium in the soil, this element was not applied. Phytosanitary treatments according to standard management practices were applied throughout the growing season. Meteorological information as to the evolution of mean temperature and the amount of rainfall during each growing season together with different phenological stages of the melon crop are graphically presented in Figures $1 \mathrm{~A}$ and $\mathrm{B}$.

\section{Plant growth}

Four plants per treatment were sampled at 34,48 , 62, and 76 DAT in both years studied. Leaves, stems and fruits were separated and weighed to obtain the fresh weight and total leaf area (LA) was measured with a leaf area meter. The leaf area index (LAI) was calculated by dividing the total leaf area by the ground area available for one plant $\left(2.25 \mathrm{~m}^{2}\right)$. The dry weight of the different aboveground plant organs was determined following oven drying at $80^{\circ} \mathrm{C}$ to constant weight. The dry weight of the melon plant was the sum of the different plant organs. 

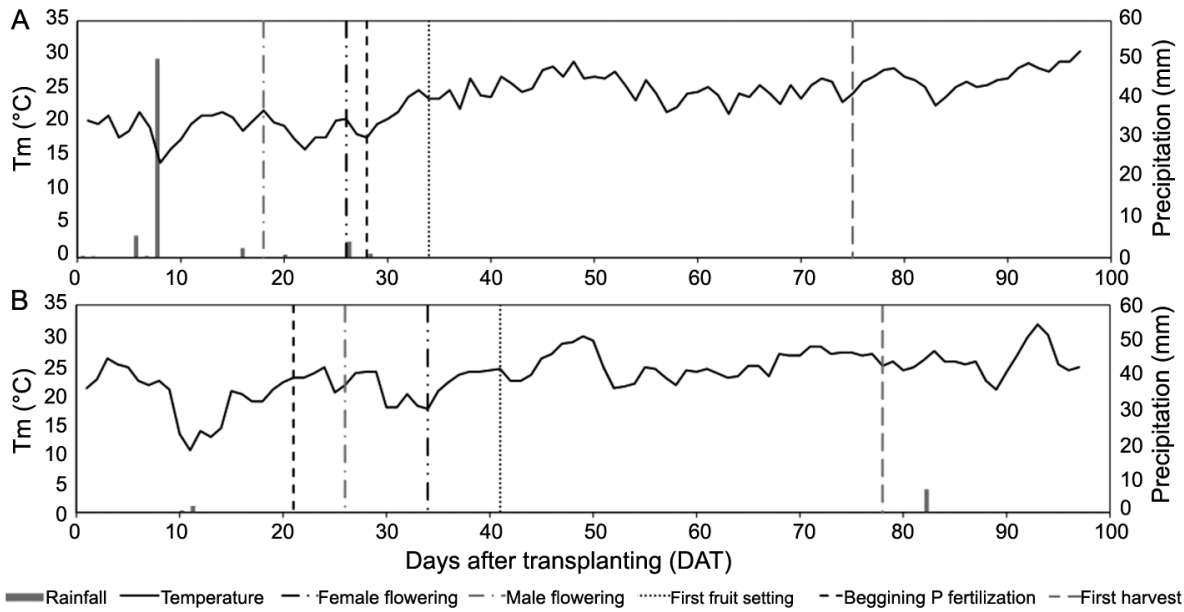

Figure 1 - Evolution of daily mean temperature (Tm) and rainfall during the crop seasons of 2011 (A) and 2012 (B). Continuous vertical lines represent the beginning of different phenological stages of the melon plant and the beginning of the irrigation schedule together with $\mathrm{P}$ fertilization.

The relative growth rate (RGR), net assimilation rate (NAR) and leaf area ratio (LAR) were calculated for each period according to de Groot et al. (2001) as: RGR $=1000 \times\left[\ln \mathrm{W}_{\mathrm{t}}-\ln \mathrm{W}_{\mathrm{t}-1}\right] /[\mathrm{t}-(\mathrm{t}-1)] ; \mathrm{NAR}=\left[\mathrm{W}_{\mathrm{t}}-\mathrm{W}_{\mathrm{t}-1}\right] /$ $[\mathrm{t}-(\mathrm{t}-1)] \times\left[\ln \mathrm{LA}_{\mathrm{t}}-\ln \mathrm{LA}_{\mathrm{t}-1}\right] /\left[\mathrm{LA}_{\mathrm{t}}-\mathrm{LA}_{\mathrm{t}-1}\right] ; \mathrm{LAR}=\mathrm{LA}_{\mathrm{t}} /$ $\mathrm{W}_{\mathrm{t}}$; where $\mathrm{W}_{\mathrm{t}}$ is the dry mass $(\mathrm{g})$ at sampling time $\mathrm{t}, \mathrm{W}_{\mathrm{t}-1}$ the dry mass $(\mathrm{g})$ at the previous sampling, LA the leaf area $\left(\mathrm{cm}^{2}\right)$ at sampling time $t, \mathrm{LA}_{\mathrm{t}-1}$ the leaf area $\left(\mathrm{cm}^{2}\right)$ at the previous sampling, and $t-(t-1)$ the time (days) between samplings. The fruit growth rate (FGR) was determined as: FGR $=\left[\mathrm{Wf}_{\mathrm{t}}-\mathrm{Wf}_{\mathrm{t}-1}\right] /[\mathrm{t}-(\mathrm{t}-1)] \times 1 / \mathrm{S}$ where $\mathrm{Wf}_{t}$ is the fruit dry mass $(\mathrm{g})$ at sampling time $\mathrm{t}, \mathrm{Wf}_{\mathrm{t}-1}$ the fruit dry mass $(\mathrm{g})$ at the previous sampling and $\mathrm{S}$ the area occupied by each plant $\left(\mathrm{m}^{2}\right)$.

\section{Nitrogen and phosphorus contents in aboveground organs}

Sub-samples of the dried plants were collected at 48 and 76 DAT, coinciding with the first fruit setting and the beginning of the harvest. These samples were ground to a fine powder to determine $\mathrm{N}$ and $\mathrm{P}$ concentrations. Total $\mathrm{N}$ was determined by the Kjeldahl method (AOAC, 1990) and total $\mathrm{P}$ was determined after digestion with $\mathrm{HNO}_{3}$ and $\mathrm{HCl}$ and measured by ICP-OES (EPA Method 3051). The $\mathrm{N}$ and $\mathrm{P}$ accumulation in every organ was obtained as the product of the concentration and dry biomass. The total plant uptake was determined as the sum of $\mathrm{N}$ or $\mathrm{P}$ accumulated in each aboveground organ of the plant.

\section{Crop yield and quality}

Melons were harvested once a significant number of fully ripe fruits had been observed in the field and harvesting was carried out weekly. Forty plants in each subplot were considered in order to determine yield and fruit quality, each melon was weighed at harvest to determine total fruit yield. For each harvest, four representative marketable fruits from each replicate were anal- ysed for fruit quality. Immediately after harvest, flesh ratio and skin ratio were determined using the formulae: $2 \times$ flesh thickness $\times$ width $^{-1}$ and $2 \times$ skin thickness $\times$ width $^{-1}$, respectively. Flesh firmness was measured in four zones of the cut equatorial surface using a penetrometer, with an $8 \mathrm{~mm}$ diameter tip measuring the force necessary to penetrate the flesh. From the liquid obtained by liquefying the mesocarp of each fruit, the total soluble solids content was determined by a handheld refractometer.

\section{Statistical analysis}

Statistical analysis was carried out for each year separately. The effect of the addition of compost was evaluated by analysis of variance (ANOVA) on the measured parameters and the statistical differences between treatments were determined by Tukey test $(p \leq 0.05)$.

\section{Results}

\section{Plant growth}

Dry matter accumulation in the aboveground melon organs in the samplings taken during the growing seasons of 2011 and 2012 is shown in Figure 2A and B. In 2011, at 48 DAT, a significant increase $(p \leq 0.05)$ in dry biomass in leaf and stem as well as in the whole plant was observed when the higher doses of compost were applied, coinciding with the first fruit setting (Figure 2A). At this stage, leaf dry biomass increased by $33 \%$ in D2 compared to D0, the stem by $42 \%$ and the whole plant by $37 \%$. This significant increase in plant biomass was accompanied by an enhancement of the LAI by $27 \%$ (D3) and $36 \%$ (D2) compared to D0 (Figure 3A). During the final stages of crop growth (76 DAT), no significant differences in the accumulation of dry biomass were observed in any of the organs nor in the whole plant. However, a positive trend of increases in plant 
dry weight and LAI with the application of compost was observed ( $p \leq 0.09$ and 0.12 respectively).

In contrast, with respect to biomass accumulation, in 2012 the major differences between treatments were observed at the end of the crop cycle (76 DAT) (Figure 2B). During this stage, a significant increase of, on average, $23 \%$ was obtained in fruit biomass with the application of compost, there being no significant differences between the different application rates. Moreover, the same enhancement was seen in leaf dry weight (76 DAT) $(p \leq 0.05)$ and, considering the whole plant biomass, the application of the three doses of compost produced an average increase of $21 \%$ compared to the control. At 76 DAT, the LAI was lower in the control plants compared to plants treated with compost $(p \leq 0.12)$.

Table 2 presents the growth parameters for each period studied. Again, the application of compost influenced these parameters in a different manner according to the year of study.

During the first period of plant development, before the appearance and setting of the first fruits (34-48 DAT), only in 2011 did the highest dose of compost (D3) enhance the relative growth rate (RGR) and net assimilation rate (NAR) of melon plants compared to the control treatment.

From the beginning of fruit growth until the reaching of maximum LAI value (48-62 DAT), the application of compost resulted in opposite effects on growth parameters depending on the year of study. In 2011, a significantly lower RGR was found in melon plants grown in the compost amended plots, which was accompanied by a decrease in NAR, especially at the highest doses (D2 and D3). For this year, no effect was observed on LAR when compost was applied. The opposite effect was observed in 2012 for the same period (48-62 DAT), when the compost presented higher values of RGR mostly due to physiological differences (NAR) in the amended plots.

In the last stage of plant development, during the senescence of the vegetative organs and fruit ripening (62-76 DAT), positive responses to the application of compost were observed in 2012 only, when significant RGR values were recorded, again as a consequence of higher NAR values.
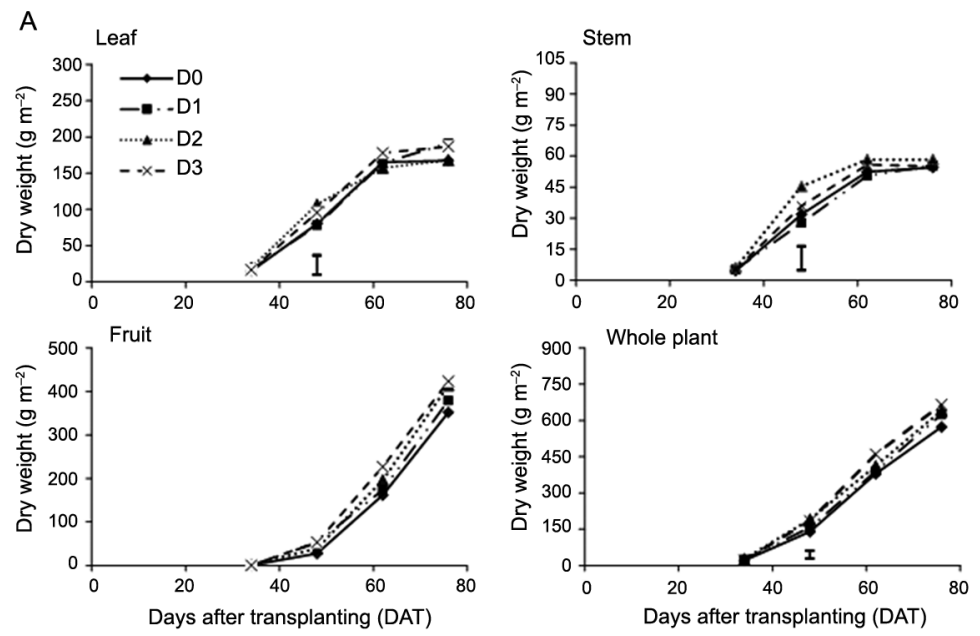

B
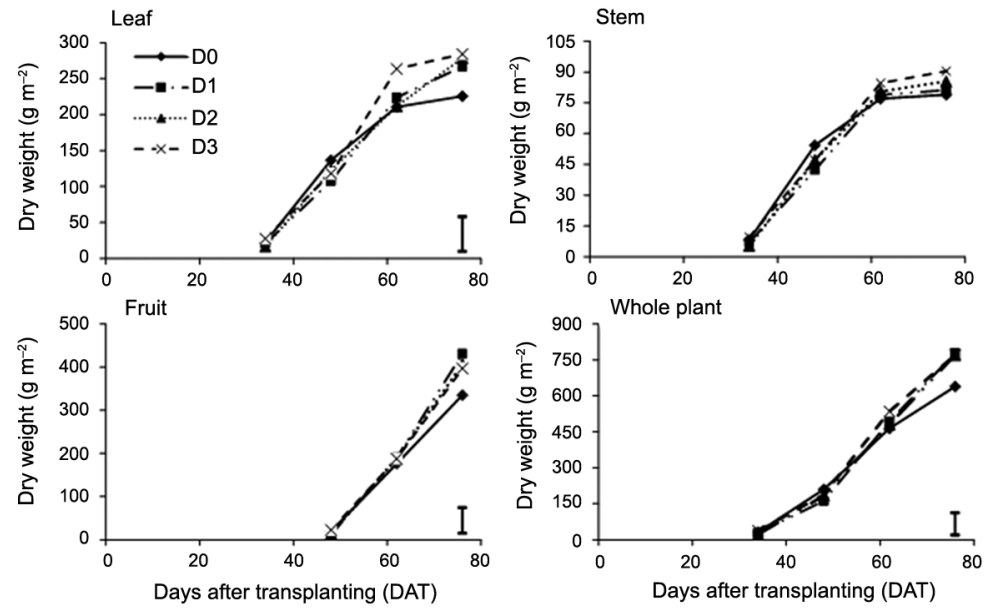

Figure 2 - Dry matter production by the aboveground organs of melon plant during the growing seasons in 2011 (A) and 2012 (B). The bars represent the least significant difference $(p \leq 0.05)$. 
The fruit growth rate (FGR) was enhanced with the application of compost for both years studied. In 2011, the application of the highest doses of compost (D2 and D3) accelerated melon fruit growth by $15 \%$ on average, whereas in 2012 this increment was $25 \%$ and no disparities were found between the different doses.

\section{Nitrogen and phosphorus contents in aboveground organs}

The application of compost had no effect on leaf, stem and fruit $\mathrm{N}$ concentrations in either of the years studied (Table 3), probably as a result of a dilution effect attributable to an increase in plant biomass in the amended plots, an effect previously reported by Greenwood et al. (1990). However, the addition of compost significantly affected the $\mathrm{N}$ uptake of the different plant parts and that of the whole plant. In 2011, total $\mathrm{N}$ uptake by the melon plants was significantly affected by the application of compost at 48 DAT (Table 3). During this stage, $\mathrm{N}$ leaf accumulation tended to increase in the amended plots compared to the control $(p \leq 0.09)$ (maximum increase of $29 \%$ with D2). This increase was statistically significant in the stem (42\% increase with D2) and consequently in the whole plant. Nevertheless, at the end of the growing cycle this effect was less pronounced and even with the addition of compost no significant differences were observed. In 2012, no significant differences were observed in $\mathrm{N}$ uptake by any plant organ at either of the two stages. However, at 76 DAT, N accumulation in the whole plant increased significantly at all levels of compost dose (33\% on average compared to control treatment), as a consequence of the tendency of leaf and fruit $\mathrm{N}$ uptake to increase following the application of compost.

The main effect of the application of compost on $\mathrm{P}$ concentration was observed at 48 DAT in the vegetative organs in both years studied, coinciding with the first fruit setting (Table 4). In 2011 at 48 DAT, the application of the higher doses of compost (D2 and D3) increased P concentration in the stem by $6 \%$ on average compared

Table 2 - Relative growth rate (RGR), net assimilation rate (NAR), leaf area ratio (LAR) and fruit growth rate (FGR) during different growth stages of melon crop.

\begin{tabular}{|c|c|c|c|c|c|c|c|c|c|c|c|}
\hline & \multirow{2}{*}{ Treatment- } & \multicolumn{3}{|c|}{$\mathrm{RGR}\left(\mathrm{mg} \mathrm{g}^{-1} \mathrm{~d}^{-1}\right)$} & \multicolumn{3}{|c|}{ NAR $\left(\mathrm{g} \mathrm{m}^{-2} \mathrm{~d}^{-1}\right)$} & \multicolumn{3}{|c|}{$\operatorname{LAR}\left(\mathrm{cm}^{2} \mathrm{~g}^{-1}\right)$} & \multirow{2}{*}{$\begin{array}{c}\text { FGR }\left(\mathrm{g} \mathrm{m}^{-2} \mathrm{~d}^{-1}\right) \\
48-76 \text { DAT }\end{array}$} \\
\hline & & 34-48 DAT & 48-62 DAT & 62-76 DAT & 34-48 DAT & 48-62 DAT & 62-76 DAT & 48 DAT & 62 DAT & 76 DAT & \\
\hline \multirow{4}{*}{2011} & DO & $138.4 \mathrm{a}$ & $71.3 b$ & $29.6 \mathrm{a}$ & $15.3 \mathrm{a}$ & $12.4 \mathrm{~b}$ & 9.1 a & 77.9 a & $45.4 \mathrm{a}$ & $23.5 \mathrm{a}$ & $11.6 \mathrm{a}$ \\
\hline & D1 & $136.5 \mathrm{a}$ & $64.5 \mathrm{ab}$ & $34.0 \mathrm{a}$ & $15.8 \mathrm{a}$ & $12.0 \mathrm{~b}$ & $10.8 \mathrm{a}$ & $76.1 \mathrm{a}$ & $40.7 \mathrm{a}$ & $24.6 \mathrm{a}$ & $11.7 \mathrm{a}$ \\
\hline & D2 & $138.3 \mathrm{a}$ & $54.7 \mathrm{a}$ & $31.5 \mathrm{a}$ & $15.7 \mathrm{a}$ & $9.3 \mathrm{a}$ & $9.1 \mathrm{a}$ & $77.5 \mathrm{a}$ & 46.9 a & $25.7 \mathrm{a}$ & $13.4 \mathrm{~b}$ \\
\hline & D3 & $151.9 b$ & $65.3 \mathrm{ab}$ & $26.3 \mathrm{a}$ & $17.4 \mathrm{~b}$ & $11.8 a b$ & $8.1 \mathrm{a}$ & $76.4 \mathrm{a}$ & $42.5 \mathrm{a}$ & $24.7 \mathrm{a}$ & $13.2 b$ \\
\hline \multirow{4}{*}{2012} & D0 & 156.8 a & $56.5 \mathrm{a}$ & 25.6 a & $14.9 \mathrm{a}$ & $8.1 \mathrm{a}$ & $5.5 \mathrm{a}$ & $87.4 \mathrm{a}$ & $57.3 \mathrm{a}$ & $30.5 \mathrm{a}$ & $11.3 \mathrm{a}$ \\
\hline & D1 & $145.1 \mathrm{a}$ & $79.7 \mathrm{~b}$ & $37.1 \mathrm{~b}$ & $13.0 \mathrm{a}$ & $11.6 \mathrm{~b}$ & $8.0 \mathrm{~b}$ & 88.3 a & $57.1 \mathrm{a}$ & $29.4 \mathrm{a}$ & $15.0 \mathrm{~b}$ \\
\hline & D2 & $155.3 \mathrm{a}$ & $68.9 \mathrm{~b}$ & $35.5 b$ & 15.9 a & $10.4 \mathrm{~b}$ & $8.1 b$ & $89.0 \mathrm{a}$ & $52.6 \mathrm{a}$ & $33.8 \mathrm{a}$ & $14.1 \mathrm{~b}$ \\
\hline & D3 & $138.8 \mathrm{a}$ & $74.8 b$ & $36.2 b$ & $12.6 \mathrm{a}$ & $11.7 \mathrm{~b}$ & $6.7 \mathrm{ab}$ & $85.4 \mathrm{a}$ & $50.8 \mathrm{a}$ & $29.8 \mathrm{a}$ & $13.4 \mathrm{~b}$ \\
\hline
\end{tabular}

Within each column and year, means followed by the same letter are not significantly different at $p \leq 0.05$.

Table 3 - Nitrogen concentration and uptake by the aboveground organs of melon plant at 48 and 76 days after transplanting (DAT).

\begin{tabular}{|c|c|c|c|c|c|c|c|c|c|}
\hline & & \multirow{2}{*}{ Treatment } & \multicolumn{3}{|c|}{$\mathrm{N}$ concentration } & \multicolumn{4}{|c|}{$\mathrm{N}$ uptake } \\
\hline & & & Leaf & Stem & Fruit & Leaf & Stem & Fruit & Whole plant \\
\hline & & & 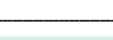 & $-\mathrm{g} \mathrm{kg}^{-1}$ & & 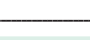 & 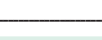 & & \\
\hline \multirow{8}{*}{2011} & \multirow{4}{*}{48 DAT } & D0 & 30.80 a & $14.23 a$ & $20.65 a$ & $2.47 \mathrm{a}$ & $0.45 a$ & $0.57 \mathrm{a}$ & $3.50 \mathrm{a}$ \\
\hline & & D1 & 29.30 a & $14.43 a$ & $24.88 a$ & $2.28 \mathrm{a}$ & $0.40 \mathrm{a}$ & $1.30 \mathrm{a}$ & $3.98 \mathrm{ab}$ \\
\hline & & D2 & 29.83 a & $14.20 \mathrm{a}$ & $21.78 \mathrm{a}$ & $3.19 a$ & $0.64 \mathrm{~b}$ & $0.86 a$ & $4.69 \mathrm{~b}$ \\
\hline & & D3 & $31.65 \mathrm{a}$ & $14.63 a$ & $20.83 a$ & $3.02 \mathrm{a}$ & $0.52 a b$ & $1.11 \mathrm{a}$ & $4.66 b$ \\
\hline & \multirow{4}{*}{76 DAT } & D0 & $19.88 \mathrm{a}$ & $13.05 \mathrm{a}$ & $14.43 a$ & $3.33 \mathrm{a}$ & $0.71 \mathrm{a}$ & $5.09 \mathrm{a}$ & $9.12 \mathrm{a}$ \\
\hline & & D1 & 19.05 a & $12.30 \mathrm{a}$ & $14.25 a$ & $3.65 \mathrm{a}$ & $0.71 \mathrm{a}$ & $5.40 \mathrm{a}$ & 9.73 a \\
\hline & & D2 & $18.53 \mathrm{a}$ & $12.80 \mathrm{a}$ & $16.20 \mathrm{a}$ & $3.11 \mathrm{a}$ & $0.72 \mathrm{a}$ & $6.72 \mathrm{a}$ & $10.57 \mathrm{a}$ \\
\hline & & D3 & $20.80 \mathrm{a}$ & $11.53 \mathrm{a}$ & $12.95 \mathrm{a}$ & $3.89 a$ & $0.64 \mathrm{a}$ & $5.49 a$ & $10.01 \mathrm{a}$ \\
\hline \multirow{8}{*}{2012} & \multirow{4}{*}{48 DAT } & DO & $40.50 \mathrm{a}$ & $22.05 a$ & $33.97 a$ & $5.53 \mathrm{a}$ & $1.20 \mathrm{a}$ & $0.66 a$ & $7.39 a$ \\
\hline & & D1 & 43.65 a & $20.60 a$ & $37.55 a$ & $4.70 \mathrm{a}$ & $0.87 \mathrm{a}$ & $0.44 \mathrm{a}$ & $6.01 \mathrm{a}$ \\
\hline & & D2 & 40.08 a & $20.97 a$ & $34.68 a$ & $4.92 \mathrm{a}$ & $0.99 a$ & $0.46 a$ & $6.38 a$ \\
\hline & & D3 & 41.57 a & $21.33 a$ & $36.33 a$ & $4.92 \mathrm{a}$ & $1.01 \mathrm{a}$ & $0.81 \mathrm{a}$ & $6.74 \mathrm{a}$ \\
\hline & \multirow{4}{*}{76 DAT } & DO & $21.55 \mathrm{a}$ & $12.40 \mathrm{a}$ & $14.87 a$ & $4.86 \mathrm{a}$ & $0.98 \mathrm{a}$ & $4.98 \mathrm{a}$ & $10.82 \mathrm{a}$ \\
\hline & & D1 & $21.45 \mathrm{a}$ & $13.47 \mathrm{a}$ & $16.23 a$ & $5.72 \mathrm{a}$ & $1.09 \mathrm{a}$ & $7.00 \mathrm{a}$ & $13.81 \mathrm{ab}$ \\
\hline & & D2 & $23.53 \mathrm{a}$ & $13.23 a$ & $17.30 \mathrm{a}$ & $6.56 \mathrm{a}$ & $1.13 \mathrm{a}$ & $7.04 \mathrm{a}$ & $14.73 \mathrm{~b}$ \\
\hline & & D3 & $23.87 \mathrm{a}$ & $14.03 \mathrm{a}$ & $16.63 \mathrm{a}$ & $6.79 \mathrm{a}$ & $1.27 \mathrm{a}$ & $6.60 \mathrm{a}$ & $14.66 \mathrm{~b}$ \\
\hline
\end{tabular}

Within each column and year, means followed by the same letter are not significantly different at $p \leq 0.05$. 
to the unamended plots. Surprisingly, in 2012, during the first half of the growing season, a negative effect of compost application was observed in leaf $\mathrm{P}$ concentration, which decreased in the two highest doses (D2 and D3) compared to the control and D1 treatments.

Phosphorus uptake followed a similar trend as N. In 2011, total P uptake by the melon plants was significantly affected by the application of compost at 48 DAT. During this stage, $\mathrm{P}$ leaf and $\mathrm{P}$ stem accumulation increased in D2 and D3 compared to the control, obtaining the greatest increase with D2 (about $38 \%$ and $54 \%$ in each plant organ, respectively), whereas the tendency to increase was also observed in the fruit itself $(p \leq 0.15)$. At the end of the crop cycle (76 DAT), the same tendency in plant $\mathrm{P}$ uptake was due to a higher content of $\mathrm{P}$ in the fruits $(p \leq 0.06)$ obtained from the plots amended with D2 and D3, increasing 47 and $22 \%$ compared to the control treatment respectively $(p \leq 0.15)$. In contrast, generally no differences in terms of plant $\mathrm{P}$ uptake were observed in the second year studied. In the first half of the growing season (48 DAT), the application of compost decreased leaf $\mathrm{P}$ accumulation. No differences in total plant uptake were observed either at 48 or at 76 DAT in 2012.

\section{Crop yield and quality}

In 2011 and 2012, there were four harvests conducted weekly commencing 75 and 78 DAT respectively. In both years of study the incorporation of compost significantly increased melon yield (Table 5). In 2011, fruit yield was significantly lower in D0 compared to D2 and D3, increasing $23 \%$ and $22 \%$ respectively, and no significant differences were found between the control and D1. However, in 2012, the improvement of crop yield with compost was observed regardless of the dose applied (11\% increase on average). In 2011, a higher number of fruits per plant was obtained with the addition of compost, following the same pattern as fruit yield, while the addition of compost had no significant effect on fruit weight. In contrast, in 2012 the enhancement of melon yield was attributed to the greater fruit weight obtained in the amended plots, increasing $0.2 \mathrm{~kg}$ on average compared to the control.

Table 4 - Phosphorus concentration and uptake by the aboveground organs of melon plant at 48 and 76 days after transplanting (DAT).

\begin{tabular}{|c|c|c|c|c|c|c|c|c|c|}
\hline & & \multirow{2}{*}{ Treatment } & \multicolumn{3}{|c|}{ P concentration } & \multicolumn{4}{|c|}{ P uptake } \\
\hline & & & Leaf & Stem & Fruit & Leaf & Stem & Fruit & Whole plant \\
\hline & & & & $-\mathrm{g} \mathrm{kg}^{-1}$ & & 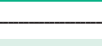 & 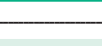 & $\mathrm{m}^{-2}$ & \\
\hline \multirow{8}{*}{2011} & \multirow{4}{*}{48 DAT } & DO & $2.91 \mathrm{a}$ & $3.70 a b$ & $4.40 \mathrm{a}$ & $0.23 a b$ & $0.12 a b$ & $0.12 \mathrm{a}$ & $0.47 a$ \\
\hline & & D1 & $2.39 \mathrm{a}$ & $3.30 \mathrm{a}$ & $4.43 \mathrm{a}$ & $0.19 \mathrm{a}$ & $0.09 a$ & $0.23 a$ & $0.51 a b$ \\
\hline & & D2 & $3.02 \mathrm{a}$ & $3.95 b$ & $4.87 \mathrm{a}$ & $0.32 b$ & $0.18 b$ & $0.19 a$ & $0.70 \mathrm{~b}$ \\
\hline & & D3 & $2.71 \mathrm{a}$ & $3.90 \mathrm{~b}$ & $4.53 \mathrm{a}$ & $0.26 a b$ & $0.14 a b$ & $0.24 \mathrm{a}$ & $0.64 a b$ \\
\hline & \multirow{4}{*}{76 DAT } & DO & $3.50 \mathrm{a}$ & $2.42 a$ & $2.97 a$ & $0.59 a$ & $0.13 a$ & $1.05 \mathrm{a}$ & $1.77 \mathrm{a}$ \\
\hline & & D1 & $3.37 \mathrm{a}$ & $2.15 \mathrm{a}$ & $2.97 \mathrm{a}$ & $0.64 \mathrm{a}$ & $0.12 \mathrm{a}$ & $1.12 \mathrm{a}$ & $1.88 \mathrm{a}$ \\
\hline & & D2 & $3.66 \mathrm{a}$ & $2.47 \mathrm{a}$ & $3.71 \mathrm{a}$ & $0.61 \mathrm{a}$ & $0.14 \mathrm{a}$ & $1.54 \mathrm{a}$ & $2.29 \mathrm{a}$ \\
\hline & & D3 & $3.26 \mathrm{a}$ & $2.14 \mathrm{a}$ & $3.03 \mathrm{a}$ & $0.61 \mathrm{a}$ & $0.12 \mathrm{a}$ & $1.28 \mathrm{a}$ & $2.01 a$ \\
\hline \multirow{8}{*}{2012} & \multirow{4}{*}{48 DAT } & D0 & $3.69 \mathrm{~b}$ & $3.62 \mathrm{a}$ & $5.48 \mathrm{a}$ & $0.50 \mathrm{~b}$ & $0.18 a$ & $0.11 \mathrm{a}$ & $0.79 a$ \\
\hline & & D1 & $3.67 b$ & $3.62 \mathrm{a}$ & $5.72 \mathrm{a}$ & $0.40 a b$ & $0.15 a$ & $0.07 a$ & $0.62 \mathrm{a}$ \\
\hline & & D2 & $3.01 \mathrm{a}$ & $3.16 \mathrm{a}$ & $5.37 \mathrm{a}$ & $0.37 a$ & $0.14 \mathrm{a}$ & $0.07 \mathrm{a}$ & $0.57 \mathrm{a}$ \\
\hline & & D3 & $3.03 \mathrm{a}$ & $3.22 \mathrm{a}$ & $5.65 \mathrm{a}$ & $0.36 \mathrm{a}$ & $0.15 \mathrm{a}$ & $0.13 a$ & $0.63 \mathrm{a}$ \\
\hline & \multirow{4}{*}{76 DAT } & D0 & $3.40 \mathrm{a}$ & $2.40 \mathrm{a}$ & $3.50 \mathrm{a}$ & $0.77 \mathrm{a}$ & $0.19 a$ & $1.17 \mathrm{a}$ & $2.13 \mathrm{a}$ \\
\hline & & D1 & $4.00 \mathrm{a}$ & $2.50 \mathrm{a}$ & $3.50 \mathrm{a}$ & $1.07 \mathrm{a}$ & $0.20 \mathrm{a}$ & $1.51 \mathrm{a}$ & $2.78 \mathrm{a}$ \\
\hline & & D2 & $3.80 \mathrm{a}$ & $2.10 \mathrm{a}$ & $3.20 \mathrm{a}$ & $1.06 \mathrm{a}$ & $0.18 a$ & $1.30 \mathrm{a}$ & $2.54 \mathrm{a}$ \\
\hline & & D3 & $3.90 \mathrm{a}$ & $2.50 \mathrm{a}$ & $3.70 \mathrm{a}$ & $1.11 \mathrm{a}$ & $0.23 a$ & $1.27 \mathrm{a}$ & $2.61 \mathrm{a}$ \\
\hline
\end{tabular}

Within each column and year, means followed by the same letter are not significantly different at $p \leq 0.05$.

Table 5 - Fruit yield, yield components and fruit quality.

\begin{tabular}{|c|c|c|c|c|c|c|c|c|}
\hline & Treatment & Fruit yield & Mean fruit weight & Fruit number per plant & Flesh ratio & Skin ratio & Flesh firmness & ${ }^{\circ}$ Brix \\
\hline & & $\mathrm{tha}^{-1}$ & $\mathrm{~kg}$ & & & & $\mathrm{~kg}$ & \\
\hline \multirow{4}{*}{2011} & DO & $29.6 a$ & $3.07 \mathrm{a}$ & $2.20 \mathrm{a}$ & $0.53 a$ & $0.079 a$ & $2.64 \mathrm{a}$ & $11.6 \mathrm{a}$ \\
\hline & D1 & $31.9 \mathrm{ab}$ & $2.91 \mathrm{a}$ & $2.48 a b$ & $0.53 \mathrm{a}$ & $0.078 \mathrm{a}$ & $2.83 a$ & $12.5 \mathrm{a}$ \\
\hline & D2 & $36.4 \mathrm{~b}$ & $3.08 \mathrm{a}$ & $2.66 \mathrm{~b}$ & $0.54 a$ & $0.081 \mathrm{a}$ & $2.85 \mathrm{a}$ & $12.3 \mathrm{a}$ \\
\hline & D3 & $36.1 \mathrm{~b}$ & $3.04 \mathrm{a}$ & $2.59 \mathrm{~b}$ & $0.54 \mathrm{a}$ & $0.077 \mathrm{a}$ & $2.87 a$ & $12.5 \mathrm{a}$ \\
\hline \multirow{4}{*}{2012} & DO & $49.9 a$ & $3.57 a$ & $3.15 \mathrm{a}$ & $0.52 a$ & $0.089 a$ & $2.91 \mathrm{a}$ & $13.3 \mathrm{a}$ \\
\hline & D1 & $55.2 \mathrm{~b}$ & $3.76 \mathrm{~b}$ & $3.30 \mathrm{a}$ & $0.52 \mathrm{a}$ & 0.089 a & $2.88 \mathrm{a}$ & $13.9 a b$ \\
\hline & D2 & $55.0 \mathrm{~b}$ & $3.79 b$ & $3.12 \mathrm{a}$ & $0.52 a$ & $0.087 a$ & $2.90 \mathrm{a}$ & $13.8 \mathrm{ab}$ \\
\hline & D3 & $56.1 \mathrm{~b}$ & $3.82 b$ & $3.22 \mathrm{a}$ & $0.54 \mathrm{a}$ & $0.086 a$ & $2.86 \mathrm{a}$ & $14.2 b$ \\
\hline
\end{tabular}

Within each column and year, means followed by the same letter are not significantly different at $p \leq 0.05$. 
With respect to the quality parameters measured, a tendency of improving flesh firmness was observed in 2011 only for all the compost treatments $(p \leq 0.14)$. The application of compost tended to increase the Brix degrees in melon in 2012 by a significant $7 \%$ although the increase in 2011 was not significant. In neither of the two years studied did the addition of compost affect the flesh to skin ratio.

\section{Discussion}

The enhancement of plant growth obtained with the addition of compost was slight, probably as a result of the large input of $\mathrm{N}$ from the irrigation water, the element that contributes primarily to plant growth. Castellanos et al. (2011) studied the effect of applying different $\mathrm{N}$ doses (from 30 to $393 \mathrm{~kg} \mathrm{~N} \mathrm{ha}^{-1}$ ) to a melon crop under fertigation and stated that leaf and stem biomass increased with the dose of $\mathrm{N}$ while the fruit biomass reached its maximum at about $90 \mathrm{~kg} \mathrm{~N} \mathrm{ha}{ }^{-1}$. Our control (D0) was supplied with $89 \mathrm{~kg} \mathrm{~N} \mathrm{ha}^{-1}$ (2011) and $132 \mathrm{~kg} \mathrm{~N} \mathrm{ha}^{-1}$ (2012) in irrigation water. Thus, it did not show any lack of this element. Additionally, the low mineralization rate of organic $\mathrm{N}$ after the application of this compost (from 5 to 15 $\%$ of total $\mathrm{N}$ applied during the growing season (Requejo et al., 2016a)| explained why we observed no substantial effect on leaf and stem biomass when compost was added. Other authors have also found positive effects on plant growth by applying a combination of inorganic fertilization and organic matter. Ahmed and Shalaby (2012) found that the application of manure compost or seaweed improved the vegetative growth of cucumber. Biochar has also been found to increase the dry weight of pepper and tomato plants grown under fertigation (Graber et al., 2010). Similarly, Tzortzakis et al. (2012) reported increases in pepper growth combining fertigation with the application of municipal solid waste compost.

The relative growth rate and its components can be used as comprehensive indicators for evaluating the effect of different growing conditions on plant growth. Other authors have reported positive effects on RGR with the use of compost in faba bean cultivation (Abdelhamid et al., 2004) or vermicompost in cucumber (Sallaku et al., 2009). In our study, changes in RGR with the application of compost were associated with physiological differences (NAR). There are wide variations in the literature regarding the importance of NAR or LAR to plant growth (Poorter and Van der Werf, 1998). De Groot et al. (2001) stated that NAR played a more important role than LAR in a tomato crop when there is no nutrient limitation. The decrease in RGR observed in 2011 with the application of compost after the appearance and setting of the first fruits (48-62 DAT) might be explained by the higher number of fruits observed in the amended plots for this particular year of study (Table 5). The decline in NAR values might be the consequence of a greater relocation of assimilates for the reproductive function and (Eckstein et al., 1995) whereby the highest loading of fruits in melon plants in the amended plots could have reduced this index. The slight enhancement in RGR and NAR in the plots amended with compost at the end of the crop growing cycle might be due to a delay in the senescence of the vegetative organs and, in consequence, a greater photosynthetic area (Figure 3A and B) (Tekalign and Hammes, 2005).

It has been confirmed that composts have the capacity to supply both micronutrients and macronutrients in the soil for optimum plant growth (Roe et al., 1997; Bustamante et al., 2008c). Nutrients in winery and distillery waste composts are present in forms readily available for plant uptake (e.g. $\mathrm{NO}_{3}{ }^{-}, \mathrm{NH}_{4}{ }^{+}$exchangeable P) (Bustamante et al., 2011), or in organically-bound forms which can be mineralized and become available in the medium or long term (Requejo et al., 2016a, b). Increases in crop yield and quality were sometimes attributed to an improved uptake of $\mathrm{N}, \mathrm{P}$ or $\mathrm{K}$ from compost (Mkhabela and Warman, 2005; Montemurro et al., 2005). In our study, the higher number of fruits per plant observed in 2011 might be attributable to a higher $\mathrm{P}$ uptake in the amended treatments (Table 4). The number of fruits produced per plant depends on the number of flowers produced and the fruit set and, according to other authors, phosphorus plays an important role in the flowering and fruit formation (Rickard, 2000). A higher number of fruits per plant was obtained with increasing $\mathrm{P}$ applications in other studies using melon crop (Mendoza-Cortez et al., 2014). In
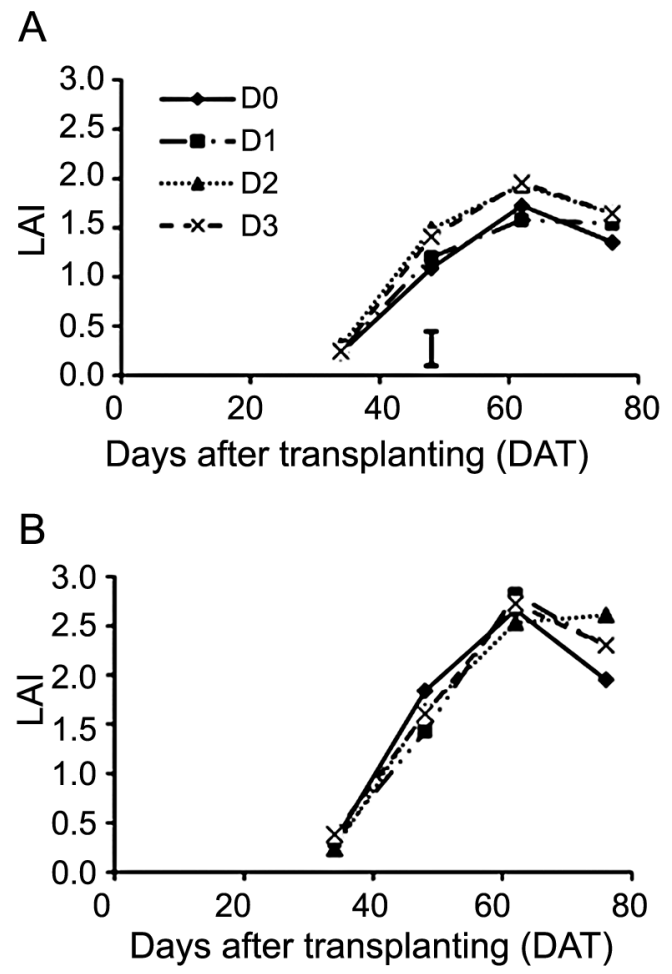

Figure 3 - Leaf Area Index (LAl) during the growing seasons in 2011 (A) and 2012 (B). The bars represent the least significant difference $(p \leq 0.05)$. 
2012, the response of plant $\mathrm{N}$ uptake was observed only at the end of the growing period (Table 3) which coincided with an enhancement in fruit weight. However, under the same experimental conditions, Castellanos et al. (2011) established an optimum $\mathrm{N}$ dose of 90-100 kg $\mathrm{ha}^{-1}$ to obtain maximum yields which is covered with $\mathrm{N}$ applied in water used for irrigation. In this case, a synergistic effect between $\mathrm{N}$ and other nutrients not studied in this work could have occurred which enhanced crop yield. Moreover, the effect of compost on melon fruit yield should not be attributed only to the higher input of nutrients, as the presence of plant growth regulators and humic acids in compost could also influence crop yield and quality. Salman et al. (2005) have reported positive effects on yield with the application of humic substances to a horticultural crop.

The two different patterns observed in both years of study regarding plant $\mathrm{N}$ and $\mathrm{P}$ uptake could be explained by directing attention to the timing of the $\mathrm{N}$ and $\mathrm{P}$ applications via fertigation (Figure $1 \mathrm{~A}$ and $\mathrm{B}$ ). The irrigation schedule usually starts approximately two weeks after transplanting (Cabello et al., 2009) coinciding with the onset of plant development. However, in 2011, due to the rainfall which occurred just before this period, the start of the irrigation schedule was delayed, beginning at 28 DAT. During this period of non-irrigation, both the male and female flowering occurred and the plant took up $\mathrm{P}$ supplied by the soil or that mineralized from the compost. This could explain the higher uptake of $\mathrm{P}$ in leaves and stems observed at 48 DAT in the amended treatments which might have been mobilized to the fruits during the fruit development period. In contrast, in 2012 the irrigation schedule began before flowering, at 21 DAT. In this case, there was an important supply of $\mathrm{N}$ and $\mathrm{P}$ during the flowering stage which suppressed the compost effect so that no differences were observed between treatments. This could indicate that under these conditions the plant $\mathrm{P}$ needs are covered with $\mathrm{P}$ applied via fertigation so that there is no additional effect when compost is added.

According to the results, the dose corresponding to $13 \mathrm{t} \mathrm{ha}^{-1}$ (D2) would be enough to achieve the greatest improvement in melon fruit yield. Moreover, in a previous study, the results obtained from nitrate leaching showed that D2 did not exceed the maximum allowable limits established by the impact indexes studied (Requejo et al., 2014). No additional effect on yield was observed between 13 and $20 \mathrm{th}^{-1}$ (D2 and D3 respectively). This effect had been previously observed by Xue and Huang (2013) using a sewage sludge compost and they attributed it to an increase in soil EC or in the content of heavy metals with the application of large amounts of sludge compost. Bustamante et al. (2011), applying different compost mixtures containing winery and distillery waste to a calcareous vineyard soil, reported an increase in $\mathrm{Zn}, \mathrm{Mn}$ and $\mathrm{Cu}$ concentrations in soil (in all cases below the toxicity thresholds) but no differences in soil EC compared to the control. The higher ac- cumulation of these metals in soil subject to application with the largest dose might explain the absence of any additional response with D3.

Our results agree with those obtained by other authors regarding the effect of organic fertilizers on fruit quality. Previous studies have indicated that flesh firmness seems to be unaffected by the application of compost, as has been found to be the case for melon (Naidu et al., 2013) and watermelon (Liguori et al., 2015). On the other hand, Fernandes et al. (2003) obtained higher soluble solid contents in melon under organic fertilization. A number of studies have shown that nitrogen influences soluble solids content (Bhella and Wilcox, 1989). However, previous studies carried out under the same experimental conditions stated that total soluble solids were not affected by the application of N (Castellanos et al., 2011, 2012). Welles and Buitelaar (1998) reported that LAI has an effect on fruit soluble solids by extending the fruit developing period resulting in an increase in total soluble solids for this crop

There was a strong effect in both years on yield and growth of melon, and higher biomass and yield was seen in 2012. Among the factors that could have influenced these differences is temperature exposure (de Köning, 1990) which was higher in 2012 (Figure 1B). Additionally, temperature fluctuations after the fruit set in 2011 may have resulted in smaller fruits due to lower cell proliferation during the early stage of fruit development (Higashi et al., 1999). Accumulated biomass was higher in 2012 than in 2011 due to a longer duration of the plant growing cycle. In 2011, due to the earlier appearance of powdery mildew, the onset of plant senescence was earlier than in 2012, which might also explain the different yields obtained in each growing season.

\section{Conclusions}

The application of compost derived from winery and distillery waste resulted in modest increases in plant biomass and leaf area index and in improvements in melon fruit yield. The dose of compost corresponding to $13 \mathrm{tha}^{-1}$ (D2) was enough to achieve the highest yield, corroborating previous studies, together with low levels of environmental risk (Requejo et al., 2014). An effect of $\mathrm{P}$ derived from the compost was observed in the plant uptake which resulted in a higher number of fruits in the amended plots. The addition of compost also influenced melon fruit quality by enhancing pulp Brix degrees.

\section{Acknowledgments}

This work was supported by the National Institute for Agriculture and Food Research and Technology (I.N.I.A.), an Agency in Spain (RTA2010-00110-C03). The authors would like to thank Agricompost S.L. for providing the compost and the personnel of 'La Entresierra' field station for their technical assistance during the field experiment. 


\section{References}

Abdelhamid, M.T.; Horiuchi, T.; Oba, S. 2004. Composting of rice straw with oilseed rape cake and poultry manure and its effects on faba bean (Vicia faba L.) growth and soil properties. Bioresource Technology 93: 183-189.

Ahmed, Y.; Shalaby, E. 2012. Effect of different seaweed extracts and compost on vegetative growth, yield and fruit quality of cucumber. Journal of Horticultural Science and Ornamental Plants 4: 235-240.

Allen, R.G.; Pereira, L.S.; Raes, D.; Smith, M. 2002. Crop Evapotranspiration: Guidelines for Computing Crop Water Requirements. 3ed. FAO, Rome, Italy. (FAO Irrigation and Drainage Paper, 56).

Association of Official Analytical Chemists [AOAC]. 1990. Official Methods of Analysis. AOAC, Arlington, VA, USA.

Bhella, H.S.; Wilcox, G.E. 1989. Lime and nitrogen influence soil acidity, nutritional status, vegetative growth, and yield of muskmelon. Journal of the American Society for Horticultural Science 114: 606-610.

Bustamante, M.; Moral, R.; Paredes, C.; Pérez-Espinosa, A.; Moreno-Caselles, J.; Pérez-Murcia, M. 2008a. Agrochemical characterisation of the solid by-products and residues from the winery and distillery industry. Waste Management 28: 372380 .

Bustamante, M.; Paredes, C.; Marhuenda-Egea; F.; PérezEspinosa, A.; Bernal, M.; Moral, R. 2008b. Co-composting of distillery wastes with animal manures: carbon and nitrogen transformations in the evaluation of compost stability. Chemosphere 72: 551-557.

Bustamante, M.; Paredes, C.; Moral, R.; Agulló, E.; Pérez-Murcia, M.; Abad, M. 2008c. Composts from distillery wastes as peat substitutes for transplant production. Resource Conservation and Recycling 52: 792-799.

Bustamante, M.; Said-Pullicino, D.; Agulló, E.; Andreu, J.; Paredes, C.; Moral, R. 2011. Application of winery and distillery waste composts to a Jumilla (SE Spain) vineyard: effects on the characteristics of a calcareous sandy-loam soil. Agriculture Ecosystems and Environment 140: 80-87.

Cabello, M.J.; Castellanos, M.T.; Romojaro, F.; Martínez-Madrid, C.; Ribas, F. 2009. Yield and quality of melón grown under diferent irrigation and nitrogen rates. Agricultural Water Management 96: 866-874.

Carmona, E.; Moreno, M.; Avilés, M.; Ordovás, J. 2012. Use of grape marc compost as substrate for vegetable seedlings. Scientia Horticulturae 137: 69-74.

Castellanos, M.T.; Cabello, M.J.; Cartagena, M.C.; Tarquis, A.M.; Arce, A.; Ribas, F. 2011. Growth dynamics and yield of melon as influenced by nitrogen fertilizer. Scientia Agricola 68: 191199.

Castellanos, M.T.; Cabello, M.J.; Cartagena, M.C.; Tarquis, A.M.; Arce, A.; Ribas, F. 2012. Nitrogen uptake dynamics, yield and quality as influenced by nitrogen fertilization in 'Piel de sapo' melon. Spanish Journal of Agricultural Research 10: 756-767.

De Groot, C.; Marcelis, L.; Van den Boogaard, R.; Lambers, H. 2001. Growth and dry-mass partitioning in tomato as affected by phosphorus nutrition and light. Plant, Cell \& Environment 24: 1309-1317.
De Köning, A. 1990. Long-term temperature integration of tomato. Growth and development under alternating temperature regimes. Scientia Horticulturae 45: 117-127.

Doorenbos, J.; Pruitt, W.O. 1977. Crop Water Requirements. FAO, Rome, Italy. (FAO Irrigation and Drainage Paper, 24).

Eckstein, K.; Robinson, J.; Davie, S. 1995. Physiological responses of banana (Musa AAA; Cavendish sub-group) in the subtropics. III. Gas exchange, growth analysis and source-sink interaction over a complete crop cycle. Journal of Horticultural Science 70: 169-180.

Fernandes, A.L.T.; Rodrigues, G.P.; Testezlaf, R. 2003. Mineral and organomineral fertirrigation in relation to quality of greenhouse cultivated melon. Scientia Agricola 60: 149-154.

Food and Agriculture Organization [FAO]. 2013. FAOSTAT database. FAO, Rome, Italy. Available at: http://faostat3.fao.org/ browse/Q/QD/E [Accessed May 30, 2016]

Graber, E.R.; Harel, Y.M.; Kolton, M.; Cytryn, E.; Silber, A.; David, D.R.; Tsechansky, L.; Borenshtein, M.; Elad, Y. 2010. Biochar impact on development and productivity of pepper and tomato grown in fertigated soilless media. Plant and Soil 337: 481-496.

Greenwood, D.; Lemaire, G.; Gosse, G.; Cruz, P.; Draycott, A.; Neeteson, J. 1990. Decline in percentage N of C3 and C4 crops with increasing plant mass. Annals of Botany 66: 425-436.

Higashi, K.; Hosoya, K.; Ezura, H. 1999. Histological analysis of fruit development between two melon (Cucumis melo L. reticulatus) genotypes setting a different size of fruit. Journal of Experimental Botany 50: 1593-1597.

Inácio, H.; Rosa, A.; Caccedil, J.; Monteiro, A.; Reis, M. 2000. Grape marc compost as an alternative growing media for greenhouse tomato. Acta Horticulturae 554: 75-82.

Liguori, L.; Pane, C.; Albanese, D.; Celano, G.; Zaccardelli, M.; Di Matteo, M. 2015. Compost and compost tea management of mini watermelon cultivations affects the chemical, physical and sensory assessment of the fruits. Agricultural Sciences 6: 117-125.

Mendoza-Cortez, J.W.; Cecílio-Filho, A.B.; Grangeiro, L.C.; Oliveira, F.H.T. 2014. Influence of phosphorus fertilizer on melon (Cucumis melo L.) production. Australian Journal of Crop Science 8: 799.

Ministerio de Agricultura y Pesca, Alimentación y Medio Ambiente [MAPAMA]. 2013. Statistical yearbook 2013. Available at: http://www.mapama.gob.es/es/estadistica/ temas/publicaciones/anuario-de-estadistica/2013/default.aspx [Accessed May 5, 2016] (in Spanish).

Mkhabela, M.; Warman, P. 2005. The influence of municipal solid waste compost on yield, soil phosphorus availability and uptake by two vegetable crops grown in a Pugwash sandy loam soil in Nova Scotia. Agriculture Ecosystems \& Environment 106: 57-67.

Montemurro, F.; Convertini, G.; Ferri, D.; Maiorana, M. 2005. MSW compost application on tomato crops in Mediterranean conditions: effects on agronomic performance and nitrogen utilization. Compost Science and Utilization 13: 234-242.

Naidu, Y.; Meon, S.; Siddiqui, Y. 2013. Foliar application of microbial-enriched compost tea enhances growth, yield and quality of muskmelon (Cucumis melo L.) cultivated under fertigation system. Scientia Horticulturae 159: 33-40. 
Poorter, H.; Van der Werf, A. 1998. Is inherent variation in RGR determined by LAR at low irradiance and by NAR at high irradiance? A review of herbaceous species. p. 309-336. In: Lambers, H.; Poorter, H.; Van, M.M.I., eds. Inherent variation in plant growth: physiological mechanisms and ecological consequences. Backhuys, Leiden. The Netherlands.

Requejo, M.I.; Cartagena, M.C.; Villena, R.; Arce, A.; Ribas, F.; Cabello, M.J.; Castellanos, M.T. 2014. Wine-distillery waste compost addition to a drip-irrigated horticultural crop of central Spain: risk assessment. Biosystems Engineering 128: 11-20.

Requejo, M.I.; Cartagena, M.C.; Villena, R.; Giraldo, L.; Arce, A.; Ribas, F.; Cabello, M.J.; Castellanos, M.T. 2016a. Nitrogen mineralization in soil after addition of wine-distillery waste compost: laboratory and field evaluation. Soil Research 54: 144-153.

Requejo, M.I.; Fernández-Rubín de Celis, M.; Martínez-Caro, R.; Castellanos, M.T.; Ribas, F.; Arce, A.; Cartagena, M.C. $2016 \mathrm{~b}$. Winery and distillery derived materials as phosphorus source in calcareous soils. Catena 141: 30-38.

Rickard, D.A. 2000. Review of phosphorus acid and its salts as fertilizer materials. Journal of Plant Nutrition 23: 161-180.

Roe, N.E.; Stoffella, P.J.; Graetz, D. 1997. Composts from various municipal solid waste feedstocks affect vegetable crops. II. Growth, yields, and fruit quality. Journal of the American Society for Horticultural Science 122: 433-437.
Sallaku, G.; Babaj, I.; Kaciu, S.; Balliu, A. 2009. The influence of vermicompost on plant growth characteristics of cucumber (Cucumis sativus L.) seedlings under saline conditions. Journal of Food, Agriculture and Environment 7: 869-872.

Salman, S.; Abou-Hussein, S.; Abdel-Mawgoud, A.; El-Nemr, M. 2005. Fruit yield and quality of watermelon as affected by hybrids and humic acid application. Journal of Applied Sciences Research 1: 51-58.

Soil Survey Staff. 2014. Keys to Soil Taxonomy. 12ed. USDANatural Resources Conservation Service, Washington, DC, USA.

Tekalign, T.; Hammes, P. 2005. Growth and productivity of potato as influenced by cultivar and reproductive growth. II. Growth analysis, tuber yield and quality. Scientia Horticulturae 105: 29-44.

Tzortzakis, N.; Gouma, S.; Dagianta, E.; Saridakis, C.; Papamichalaki, M.; Goumas, D.; Manios, T. 2012. Use of fertigation and municipal solid waste compost for greenhouse pepper cultivation. The Scientific World Journal, Article ID 973193. http://dx.doi.org/10.1100/2012/973193

Welles, G.; Buitelaar, K. 1988. Factors affecting soluble solids content of muskmelon (Cucumis melo L.). Netherlands Journal of Agricultural Science 36: 239-246.

Xue, D.; Huang, X. 2013. The impact of sewage sludge compost on tree peony growth and soil microbiological, and biochemical properties. Chemosphere 93: 583-589. 